BIODIK: Jurnal IImiah Pendidikan Biologi
ISSN 2580-0922 (online), ISSN 2460-2612 (print)
Volume 6, Nomor 02, Tahun 2020, Hal. 145-158
Available online at:
https://online-journal.unja.ac.id/biodik

Research Article OPEN ACCESS

\title{
Meningkatkan Motivasi Belajar Peserta Didik Dengan Menggunakan Media Modul Elektronik Di Era Revolusi Industri 4.0
}

\author{
(Improving Students' Learning Motivation through Electronic Module Media in the Industrial \\ Revolution 4.0)
}

\author{
Zaharah ${ }^{*}$, Ade Susilowati \\ SMP Negeri 22 Kota Jambi Jl. HM. Thaib Fahruddin \\ Simp. Rimbo, Kenali Besar, Alam Barajo, Jambi-Indonesia 36361 \\ * Corresponding Author : Zaharah.calut@gmail.com
}

\begin{tabular}{|c|c|}
\hline Informasi Artikel & ABSTRACT \\
\hline $\begin{array}{l}\text { Submit: } 08-05-2020 \\
\text { Diterima: } 17-05-2020 \\
\text { Dipublikasikan:06-06-2020 }\end{array}$ & $\begin{array}{l}\text { There are problems related to learning motivation that occurred in } \\
\text { SMP Negeri } 22 \text { according to the observation conducted: passive } \\
\text { learning environment and lack of students' participation, readiness } \\
\text { and engagement in learning that lead to the students' poor academic } \\
\text { achievement. In order to overcome the problems, the researchers in } \\
\text { this study used electronic module due to its practicality, efficiency and } \\
\text { interesting features that it has: audio, animation and video. Electronic } \\
\text { module has a potential to bring abstract content into more concrete for } \\
\text { the students, so that they might feel more motivated to learn. The } \\
\text { purpose of this study was to determine the effect of Electronic Module } \\
\text { Media on the stduents' learning motivation in Class VIII E SMP Negeri } \\
22 \text { Jambi city. The research method applied is classroom action } \\
\text { research. The results show that the use of electronic module media } \\
\text { has increased the students' motivation to learn, this can be seen from } \\
\text { the results of the questionnaire as follows: 0\% agree that the media is } \\
\text { lacking, } 16.7 \% \text { agree that it is sufficiently good, 56.7\% agree that it is } \\
\text { good and } 26.7 \% \text { agree that it is categorized as very good and able to } \\
\text { give a positive impact on the students' learning outcomes on } \\
\text { cognitive, affective and psychomotor aspect. This can be seen from } \\
\text { the cognitive learning outcomes of the students who have completed } \\
\text { learning that reached } 86.67 \% \text { with an average score of } 75.3 \text {. The } \\
\text { students successfully achieved good categories on affective and } \\
\text { psychomotor aspects. } \\
\text { Keywords: Media, Electronic Module, Learning Motivation. }\end{array}$ \\
\hline Penerbit & ABSTRAK \\
\hline $\begin{array}{l}\text { Program Studi Pendidikan } \\
\text { Biologi, Fakultas Keguruan dan } \\
\text { Ilmu Pendidikan, Universitas } \\
\text { Jambi }\end{array}$ & $\begin{array}{l}\text { Masalah yang peneliti temukan di SMP Negeri } 22 \text { kota Jambi adalah } \\
\text { peserta didik motivasi belajarnya sangat kurang hal ini tampak dari } \\
\text { sikap peserta didik kurang bersemangat, dan kurang siap dalam } \\
\text { mengikuti pembelajaran, sehingga suasana belajar kurang aktif, } \\
\text { interaksi antara guru dengan peserta didik atau peserta didik dengan } \\
\text { peserta didik sangat kurang, cenderung pasif, hanya menerima saja } \\
\text { apa yang diberikan guru, akibatnya hasil belajar peserta didik } \\
\text { rendah. Untuk mengatasi masalah ini, peneliti menggunakan modul } \\
\text { elektronik, karena lebih praktis untuk dibawa kemanapun,biaya } \\
\text { produksi lebih murah,tahan lama dan dapat dilengkapi dengan audio, } \\
\text { animasi dan video dalam penyajiannya. Modul elektronik tampilanya } \\
\text { menarik, dan dapat membuat materi pembelajaran yang bersifat } \\
\text { abstrak menjadi konkret sehinggasiswa termotivasi untuk belajar. }\end{array}$ \\
\hline
\end{tabular}


Tujuan penelitian iniUntuk mengetahui pengaruh penggunaan Media Modul Elektronik terhadap motivasi belajar peserta didik di Kelas VIII E SMP Negeri 22 kota Jambi. Metode Penelitian adalah Penelitian Tindakan Kelas( classroom action research). Hasil penelitian menunjukkan penggunaan media modul elektronik meningkatkan motivasi belajar kelas VIII E SMP Negeri 22 Kota Jambi, hal ini dapat dilihat dari dari hasil angket sebagai berikut : kriteria kurang $0 \%$, cukup $16,7 \%$, baik $56,7 \%$ dan kriteria sangat baik $26,7 \%$ dan berdampak positif pada hasil belajar, baik hasil belajar kognitif, afektif maupun psikomotorik. Hal ini dapat dilihat dari hasil belajar kognitif peserta didik yang telah tuntas belajar sebesar $86,67 \%$ dengan nilai rata-rata 75,3. Dengan kategori afektif dan psikomotorik baik.

Kata kunci: Media, Modul Elektronik, Motivasi Belajar

This BIODIK : Jurnal IImiah Pendidikan Biologi is licensed under a CC BY-NC-SA (Creative Commons Attribution-ShareAlike 4.0 International License)

\section{PENDAHULUAN}

Dewasa ini gaung revolusi industri 4.0 semakin membahana, bahkan revolusi industri ini telah merambah dunia pendidikan. Era pendidikan yang dipengaruhi oleh revolusi industri 4.0 disebut Pendidikan 4.0 bercirikan pemanfaatan teknologi digital dalam proses pembelajaran yang dikenal dengan sistem siber (cyber sistem) mampu membuat proses pembelajaran berlangsung secara kontinu tanpa batas ruang dan tanpa batas waktu. Menghadapi tantangan yang besar era revolusi industri 4.0 ini, maka pendidikan dituntut untuk berubah (Darmawan, 2018).

Kenyataannya berdasarkan hasil observasi peneliti permasalahan yang saat ini dihadapi guru IPA adalah belum semua guru menguasai teknologi digital, terutama di SMP Negeri 22 kota Jambi dari 5 orang guru IPA hanya satu orang memiliki tingkat pengetahuan TIK tinggi, dua orang dalam kategori sedang dan dua orang kategori rendah (Rasyidah, 2015) selain itu banyak peserta didik menganggap pelajaran IPA merupakan pelajaran yang sulit. Salah satu kesulitan belajar IPA menurut peserta didik berdasarkan hasil wawancara dengan peserta didik yaitu karena materi IPA cenderung banyak hafalan dan bersifat abstrak. Pada umumnya motivasi belajar peserta didik sangat kurang, hal ini tampak dari sikap peserta didik kurang bersemangat, dan kurang siap dalam mengikuti pembelajaran, sehingga suasana belajar kurang aktif, interaksi antara guru dengan peserta didik atau peserta didik dengan peserta didik sangat kurang, peserta didik cenderung pasif, hanya menerima saja apa yang diberikan guru, akibatnya hasil belajar peserta didik rendah.

Kurangnya motivasi peserta didik disebabkan merasa kesulitan dalam mempelajari materi IPA terutama sistem pernafasan dan sistem peredaran darah karena bersifat abstrak. Selain itu faktor penyebab rendahnya motivasi belajar peserta didik adalah media yang digunakan kurang menarik. Menurut Mc Donald dalam Kompri (2016:229) motivasi adalah suatu perubahan energi di dalam pribadi seseorang yang ditandai dengan timbulnya afektif (perasaan) dan reaksi untuk mencapai tujuan.. Dalam proses pembelajaran, motivasi belajar merupakan aspek 
yang sangat penting. Motivation is an essential condition of learning. Jika ada motivasi untuk belajar maka akan berdampak positif pada hasil belajar.

Berdasarkan fakta ini, peneliti berusaha memfasilitasi peserta didik dalam proses pembelajaran dengan media yang menarik berupa modul elektronik hasil pengembangan peneliti sendiri. Modul merupakan bahan ajar yang efektif dalam mencapai tujuan pembelajaran. Daryanto (2013: 9) menyatakan modul sebagai paket belajar mandiri yang dirancang secara sistematis untuk membantu peserta didik mencapai tujuan belajar. Seiring dengan kemajuan teknologi, modul dapat disajikan dalam format digital. Modul elektronik atau e-modul merupakan tampilan informasi dengan bentuk penyajian bahan belajar mandiri yang disusun secara sistematis ke dalam unit pembelajaran terkecil untuk mencapai tujuan pembelajaran tertentu yang disajikan dalam format buku secara elektronik dengan menggunakan hard disk, disket, CD, atau flash disk dan dapat dibaca dengan menggunakan komputer atau alat pembaca buku elektronik. Modul eletronik merupakan media yang dapat menyampaikan gambar, video dan animasi untuk meningkatkan pemahaman siswa (Anggereini, E, 2017).

Modul elektronik memiliki lebih banyak kelebihan dibandingkan modul cetak karena lebih praktis untuk dibawa kemanapun karena bentuknya yang tidak besar dan tidak berat,menggunakan CD, USB Flashdisk, atau memori card sebagai medium penyimpanan datanya,biaya produksi lebih murah, Untuk memperbanyak produk bisa dilakukan dengan mengcopy file antar user,pengiriman atau distribusi bisa dilakukan dengan menggunakan e-mail, tahan lama, tergantung dengan medium yang digunakan,naskahnya dapat disusun secara liner maupun non linier dan dapat dilengkapai dengan audio, animasi dan video dalam penyajiannya (Tim UNY,2016). Selanjutnya Munadi (2016:3) menyatakan bahwa modul elektronik memiliki beberapa kelebihan diantaranya adalah : merupakan media pembelajaran yang sangat efektif serta dapat memudahkan belajar serta meningkatkan kualitas pembelajaran, dapat meningkatkan motivasi belajar, dapat digunakan sebagai penyampaibalikan langsung dan segera secara efektif kepada pebelajar, sangat mendukung pembelajaran individual, melatih pebelajar untuk terampil memilih bagian-bagian isi pembelajaran yang dikehendaki, memungkinkan pebelajar untuk lebih mengenal dan terbiasa dengan komputer yang semakin penting di masyarakat modern, dan menjadi lebih menarik karena dilengkapi dengan fasilitas warna, lagu, gambar, grafik dan animasi sehingga mampu menyajikan pembelajaran secara menarik. Menurut Gunawan dengan adanya modul elektronik yang bersifat interaktif ini proses pembelajaran akan melibatkan tampilan audio visual, sound, movie dan yang lainnya serta program tersebut pemakaiannya mudah dipahami sehingga dapat dijadikan media pembelajaran yang baik (Sugianto, 2013 : 102).

Dari uraian tersebut, penggunaan modul elektronik memiliki kelebihan seperti dapat diintegrasikan dengan internet, jika menggunakan aplikasi yang mendukung, dan dapat langsung memutar video dan musik di dalam aplikasi tersebut. Berdasarkan pengalaman peneliti melaksanakan pembelajaran Daring selama masa darurat penyebaran Virus Corona (COVID 19) mulai Selasa, 17 Maret 2020, pembelajaran dilaksanakan secara online, sangat terasa pentingnya media pembelajaran elektronik. Pembelajaran Daring(dalam jaringan) tidak bisa 
menggunakan modul cetak, peserta didik dan guru terhubung secara elektronik. Materi-materi IPA banyak yang bersifat abstrak menyebabkan peserta didik mengalami kesulitan untuk memahaminya. Untuk itulah perlu dilakukan Penelitian Tindakan Kelas menggunakan media modul elektronik untuk meningkatkan motivasi belajar peserta didik ini. Penggunaan media modul elektronik ini diharapkan dapat meningkatkan motivasi belajar peserta didik yang bermuara pada peningkatan hasil belajar. Modul Elektonik ini dapat digunakan sebagai media pembelajaran yang menarik, dan dapat membuat materi pembelajaran yang bersifat abstrak menjadi konkret sehingga peserta didik termotivasi untuk belajar.

Hasil penelitian yang dilakukan oleh Diah (2019) tentang Penerapan Media Pembelajaran Fisika Menggunakan Modul Cetak dan Modul Eletronik Pada Siswa SMA menyatakan bahwa penggunaan modul cetak efektif untuk diterapkan dalam menunjang keterampilan abad 21. Selain itu, modul cetak juga dapat efektif untuk meningkatkan hasil belajar siswa. Sedangkan modul elektronik sangat efektif untuk meningkatkan motivasi belajar siswa, disamping itu efektif juga untuk meningkatkan hasil belajar siswa, serta kemampuan berpikir kritis. Penelitian lainnya dilakukan oleh Rohmad (2011) dengan judul Usaha meningkatkan motivasi dan prestasi belajar siswa dengan menggunakan metode eksperimen yang dibantu media animasi komputer pada materi cahaya di SMP Negeri 1 Tulungagung. Persamaan penelitian tersebut dengan penelitian yang dilaksanakan oleh peneliti adalah sama-sama berupaya meningkatkan motivasi belajar peserta didik dan sama-sama menggunakan media animasi komputer (modul elektronik).

Berdasarkan latar belakang tersebut, maka dilakukan penelitian Tindakan Kelas dengan judul " Meningkatkan Motivasi Belajar Peserta Didik dengan Menggunakan Media Modul Elektronik di era revolusi industri 4.0”. Berdasarkan latar belakang yang telah dikemukakan, maka dirumuskan masalah penelitian ini yaitu : Apakah Penggunaan Media Modul Elektronik dapat Meningkatkan Motivasi Belajar Peserta Didik? Tujuan penelitian penelitian ini adalah :Untuk mengetahui pengaruh penggunaan Media Modul Elektronik terhadap motivasi belajar peserta didik.

\section{METODE PENELITIAN}

Jenis penelitian ini adalah Penelitian Tindakan Kelas (PTK). Penelitian Tindakan Kelas (PTK) adalah penelitian tindakan (action research) yang dilakukan guru yang bertindak sebagai peneliti atau guru bekerja sama dengan peneliti di ruang kelas atau tempat guru tersebut mengajar dengan penekanan pada penyempurnaan atau peningkatkan proses dan praktis pembelajaran. Langkah-langkah penelitian adalah sebagai berikut : Perencanaan, Pelaksanaan, Observasi dan Refleksi.

Penelitian ini dilaksanakan di kelas VIII E SMP Negeri 22 Kota Jambi, dengan jumlah siswa 30 orang yang terdiri dari 19 orang putri dan 11 orang putra. Lokasi penelitian adalah SMP Negeri 22 kota Jambi, yang terletak di RT 8, Kelurahan Kenali Besar, Kecamatan Kota Baru, kota Jambi. Alasan peneliti melaksanakan penelitian di SMP Negeri kota Jambi, karena peneliti adalah guru yang mengajar di SMP Negeri 22 kota Jambi kelas VIII, yang mengetahui karateristik peserta didik kelas VIII dan semua masalah yang dihadapi oleh peserta didik kelas VIII khususnya kelas VIII E yang menjadi subjek penelitian.

\section{Syahriani. $d k k$}


Penelitian ini dilaksanakan pada semester 2 tahun pembelajaran 2017/2018 sejak tanggal 16 Januari 2018 sampai dengan tanggal 31 Maret 2018. Penentuan waktu penelitian dilakukan berdasarkan kalender akademik yang ada di SMP Negeri 22 kota Jambi. Penelitian ini terdiri dari langkah-langkah sebagai berikut : Perencanaan, Pelaksanaan, Observasi dan Refleksi. Desain Penelitian Tindakan Kelas yang diterapkan oleh peneliti dapat dilihat pada gambar 1 .

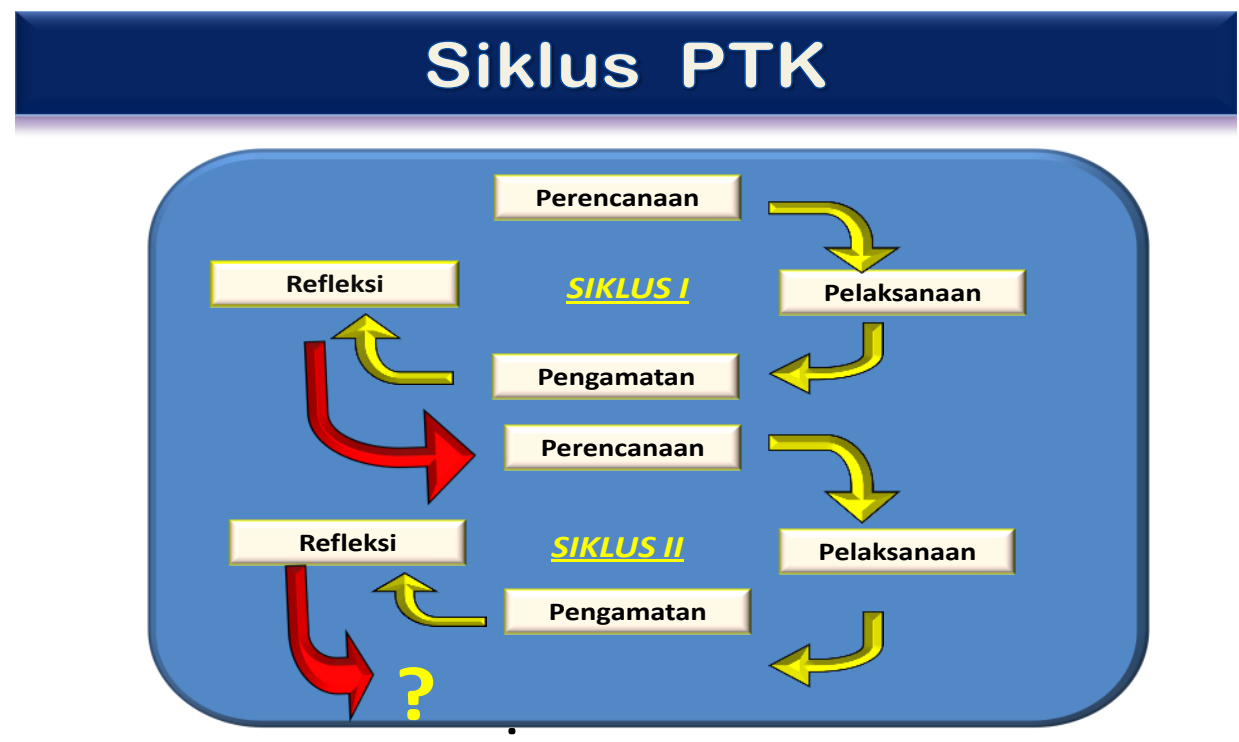

Gambar 1.Alur Pelaksanaan Tindakan dalam Penelitian indakan Kelas.

\section{Rancangan Siklus 1}

\section{a. Tahap Perencanan}

Peneliti dalam tahap perencanaan ini menyusun langkah-langkah meliputi (1) Merancang skenario pembelajaran IPA menggunakan Media Pembelajaran. (2) Menyusun rencana pembelajaran tentang Sistem Pernafasan. (3) Guru menyiapkan Mediayang diperlukan. (4) Melakukan kolaborasi dengan guru IPA yang lain. (5) Merancang tes siklus I dan kunci jawabannya. (6) Membuat lembar observasi. (7) Membuat angket.

\section{b. Tahap Pelaksanaan}

Pelaksanaan tindakan dengan mengimplementasikan perencanaan yang dipersiapkan yaitu pelaksanaan pembelajaran menggunakan Media Pembelajaran.

\section{c. Tahap Observasi}

Kegiatan observasi dilaksanakan untuk mengamati tingkah laku dan sikap peserta didik dan guru ketikamelaksanakan pembelajaran IPA denganmenggunakan media pembelajaran.

\section{d. Tahapan Analisis dan Refleksi}

Setelah dilaksanakan kegiatan pembelajaran dan berdasarkan hasil pengamatan yang ada, peneliti menganalisis hasil yang diperoleh. Apabila setelah 
dilakukan tindakan masih ditemukan masalah yang belum terpecahkan maka peneliti melanjutkan ke siklus berkutnya. Pada siklus kedua ini terjadi revisi rencana tindakan pertama sesuai keadaan di lapangan.

\section{Rancangan Siklus II}

Pada rancangan siklus II ini tindakan diambil dari hasil yang telah dicapai pada siklus 1 sebagai usaha perbaikan.

\section{Teknik Pengumpulan Data}

Pengumpulan data dilakukan dengan cara observasi menggunakan lembar observasi. Pengukuran Motivasi menggunakan angket. Penilaian hasil belajar kognitif dilakukan dengan tes tertulis, sebagai kegiatan akhir dari proses pembelajaran.

\section{Teknik Analisis Data}

Teknik analisis data kualitatif, data-data yang terkumpul berupa kalimatkalimat dianalisis melalui tahap-tahap reduksi data, penyajian data, serta penarikan kesimpulan, selain itu ada data kuantitatif yang digunakan sebagai data pendukung dari hasil tes.

\section{HASIL DAN PEMBAHASAN}

\section{Deskripsi Lokasi Penelitian}

Penelitian dilaksanakan di kelas VIII E SMP Negeri 22 Kota Jambi, dengan 30 peserta didik. Dalam proses pembelajaran yang dilaksanakan di VIII E SMP Negeri 22 Kota Jambi motivasi belajar peserta didik rendah, hal ini terlihat dari indikatorpada umumnya peserta didik menampakkan sikap kurang bersemangat, dan kurang siap dalam mengikuti pembelajaran, sehingga suasana belajar kurang aktif, interaksi antara guru dengan peserta didik atau peserta didik dengan peserta didik sangat kurang, peserta didik tidak termotivasi, cenderung pasif, hanya menerima saja apa yang diberikan guru. Untuk mengatasi masalah tersebut peneliti melaksanakan pembelajaran menggunakan media pembelajaran yang berbentuk modul elektronik hasil pengembangan peneliti sendiri yang dapat meningkatkan motivasi belajar peserta didik.

\section{Deskripsi Prosedur dan Hasil Penelitian}

\section{Tindakan siklus 1}

Tindakan siklus I dilakanakanpada tanggal 16 Januari,23 Januari dan tanggal 30 Januari 2018 sebanyak 3 kali pertemuan. Tiap pertemuan 2x40 menit, Adapun tahapan yang dilakukan meliputi:

\section{a. Tahap perencanaan}

Berdasarkan data hasil pengamatan langsung terhadap pelaksanaan pembelajaran yang dilakukan guru dalam menyampaikan belajar IPA materi sistem 
pernapasan untuk mengetahui gambaran awal kegiatan pembelajaran di kelas VIII E SMP Negeri 22 Kota Jambi masih terdapat banyak kekurangan, antara lain guru kurang dapat menciptakan suasana belajar yang menyenangkan (respon peserta didik kurang), motivasi belajar kurang sehingga berdampak pada hasil ketuntasan belajar siswa kelas VIII E . Nilai prestasi belajar kognitif siswa diperoleh dari tes objektif.

Berdasarkan data nilai dapat dilihat bahwa sebelum dilaksanakan tindakan, peserta didik kelas VIII E SMP Negeri 22 Kota Jambi sebanyak 30 siswa hanya 8 siswa atau $27.00 \%$ yang memperoleh nilai di atas batas nilai ketuntasan minimal. Maka peneliti mengadakan diskusi dengan guru sejenis untuk melaksanakan pembelajaran dengan menggunakan media pembelajaran.

Tabel 1 Hasil Tes Awal

\begin{tabular}{c|c}
\hline Keterangan & Ujian Awal \\
\hline Nilai terendah & 30.00 \\
Nilai tertinggi & 80.00 \\
Rata-rata nilai & 5.50 \\
Siswa belajar tuntas & $27.00 \%$ \\
\hline
\end{tabular}

Analisis hasil evaluasi dari tes awal peserta didik diperoleh nilai rata-rata kemampuan peserta didik menjawab soal dengan benar adalah 5,50 di mana hasil tersebut masih di bawah rata-rata nilai yang diinginkan dari pihak guru, peneliti, dan sekolah yaitu sebesar 70 . Sedangkan besarnya persentase siswa tuntas pada materi sistem pernapasan sebesar $27.00 \%$, dari pihak sekolah ketuntasan peserta didik diharapkan mencapai lebih dari $85.00 \%$. Dari hasil observasi dan analisis tes awal tersebut, maka dilakukan tindakan untuk meningkatkan motivasi belajar peserta didik yang diharapkan berdampak pada prestasi belajar, khususnya untuk materi pokok sistem pernapasan.

Berdasarkan hasil observasi motivasi belajar peserta didik rendah dan dari hasil tes awal pada tabel 2 ditegaskan bahwa penguasaan materi sistem pernapasan oleh siswa kelas VIII E SMP Negeri 22 Kota Jambi masih kurang. Adanya beberapa indikator yang masih memiliki porsi jawaban yang kurang dari $70.00 \%$ memberikan indikasi bahwa peserta didik masih belum begitu paham pada beberapa indikator materi pokok sistem pernapasan. Sebagai langkah awal peneliti menyusun lembar observasi yang akan digunakan untuk mengetahui hasil belajar afektif dan psikomotorik peserta didik selama proses pembelajaran dan observasi keterampilan mengajar guru menggunakan media pembelajaran, angket untuk mengetahui motivasi peserta didik, sedangkan sebagai alat evaluasinya peneliti membuat soal ulangan berbentuk objektif untuk mengetahui tingkat pemahaman peserta didik terhadap materi sistem pernapasan.

\section{b. Pelaksanaan Tindakan}

Guru melaksanakan pembelajaran dengan megunakan media pembelajaran sesuai dengan pelaksanaan pembelajaran yang telah disusun. Dalam kegiatan belajar mengajar, guru berusaha menyampaikan materi sistem pernapasan dengan menggunakan media pembelajaran berupa balon karet. 
c. Observasi

Observer melakukan pengamatan tingkah laku dan sikap peserta didik selama proses pembelajaran dengan menggunakan media balon karet serta mengamati keterampilan guru dalam mengajar dengan menggunakan media pembelajaran. Peneliti menemukan ada peserta didik yang bermain-main dengan balonnya, balon yang seharusnya ditiup satu kali, ditupnya berkali-kali sehingga balonnya membesar bahkan ada yang pecah sehingga menimbulkan kegaduhan di kelas karena suaranya mengagetkan, peserta didik yang perempuan bahkan ada yang berteriak karena kaget.

\section{d. Refleksi}

Dari hasil temuan pada siklus 1, maka peneliti merencanakan tindakan untuk mengubah media pembelajaran balon dengan media modul elektronik hasil pengembangan peneliti sendiri untuk materi sistem peredaran darah sehingga diharapkan peserta didik akan termotivasi untuk belajar dan tidak main-main lagi, karena modul elektronik yang peneliti kembangkan lebih menarik. Sikap peserta didik yang bermain-main saat kegiatan pembelajaran berdampak pada hasil belajarnya walaupun pada umumnya peserta didik sudah termotivasi untuk belajar dengan penggunaan media balon dibandingkan bila menggunakan metode ceramah. Berdasarkan hasil angket motivasi belajar peserta didik kriteria kurang $10.00 \%$, cukup $46.70 \%$, baik $36.70 \%$ dan sangat baik $6.70 \%$ dari hasil tes masih ada 18 peserta didik yang belum mencapai KKM. Untuk peserta didik yang belum tuntas ini peneliti melakukan kegiatan remedial kemudian peneliti melanjutkan siklus ke II untuk materi sistem peredaran darah dengan menindaklanjuti siklus I.

Tabel 2. Frekuensi Nilai Hasil Belajar Siklus I

\begin{tabular}{|c|c|c|c|}
\hline Nomor & Nilai & Frekuensi & Prosentase \\
\hline 1 & $21.00-30.00$ & 0 & $0.00 \%$ \\
\hline 2 & $31.00-40.00$ & 1 & $3.33 \%$ \\
\hline 3 & $41.00-50.00$ & 5 & $16.67 \%$ \\
\hline 4 & $51.00-60.00$ & 3 & $10.00 \%$ \\
\hline 5 & $61.00-70.00$ & 9 & $30.00 \%$ \\
\hline 6 & $71.00-80.00$ & 10 & $33.33 \%$ \\
\hline 7 & $81.00-90.00$ & 2 & $6.67 \%$ \\
\hline 8 & $91.00-100.00$ & 0 & $0.00 \%$ \\
\hline Jumlah & & 30 & $100.00 \%$ \\
\hline
\end{tabular}

Dari data tersebut dapat ditegaskan bahwa setelah melaksanakan siklus 1 , peserta didik memperoleh nilai 40.00 sebanyak 1 orang atau $3.33 \%$, peserta didik memperoleh nilai 50.00 sebanyak 5 orang atau $16.67 \%$, peserta didik mendapat nilai 60.00 sebanyak 3 orang atau $10.00 \%$, peserta didik mendapat nilai 70.00 sebanyak 9 orang atau $30.00 \%$, peserta didik mendapat nilai 80.00 sebanyak 3 orang atau $10.00 \%$, dan peserta didik mendapat nilai 90.00 sebanyak 2 orang atau $6.67 \%$. 
Tabel 3. Perkembangan Prestasi Belajar Tes Awal dan Tes Siklus I

\begin{tabular}{ccc}
\hline Keterangan & Tes Awal & Siklus I \\
\hline Nilai terendah & 30.00 & 40.00 \\
Nilai tertinggi & 80.00 & 90.00 \\
Rata-rata nilai & 5.50 & 6.47 \\
\hline Siswa belajar tuntas & $27.00 \%$ & $40.00 \%$ \\
\hline
\end{tabular}

Dari hasil analisa data perkembangan prestasi belajar peserta didik pada tes siklus I tabel 3 dapat disimpulkan bahwa persentasi hasil tes peserta didik yang tuntas naik $13.00 \%$ dengan nilai batas tuntas 70 ke atas, peserta didik yang tuntas belajar di siklus I sebesar $40.00 \%$, yang semula pada tes awal hanya terdapat 27.00 $\%$ peserta didik mencapai batas tuntas. Besarnya nilai terendah yang diperoleh peserta didik pada saat tes awal sebesar 30.00 dan pada siklus I menjadi 40.00 . Untuk nilai tertinggi terdapat kenaikan dari 80.00 naik menjadi 90.00 dan nilai ratarata kelas yang pada tes awal sebesar 5.50 naik pada tes siklus I menjadi 6.47 nilai tersebut belum mencapai rata-rata nilai yang diinginkan dari pihak guru, peneliti dan sekolah. Dalam penelitian tindakan kelas siklus I masih banyak ditemukan kekurangan-kekurangan.

\section{Tindakan Siklus II}

Tindakan siklus II dilaksanakan 27 Februari 2018 sampai 6 Maret 2018, kegiatan dilaksanakan 2 kali pertemuan. Tiap-tiap pertemuan lamanya $2 \times 40$ menit.Pembelajaran dilaksanakan menggunakan media modul elktronik.

Tabel 4. Hasil Angket Motivasi Belajar IPA

\begin{tabular}{ccccc}
\hline \multirow{2}{*}{ Kriteria } & \multicolumn{2}{c}{ Siklus I } & \multicolumn{2}{c}{ Siklus II } \\
\cline { 2 - 5 } & Jumlah & $\%$ & Jumlah & $\%$ \\
\hline Kurang & 3 orang & $10.00 \%$ & 0 & $0.00 \%$ \\
Cukup & 14 orang & $46.70 \%$ & 5 orang & $16.70 \%$ \\
Baik & 11 orang & $36.70 \%$ & 17 orang & $56.70 \%$ \\
Sangat Baik & 2 orang & $6.70 \%$ & 8 orang & $26.70 \%$ \\
\hline Jumlah & 30 orang & $100.00 \%$ & 30 orang & $100 \%$ \\
\hline
\end{tabular}

Dari tabel 4 dapat ditegaskan bahwa terjadi peningkatan motivasi belajar siswa pada siklus II, hal ini dapat dilihat, pada siklus I kriteria kurang $10.00 \%$, cukup $46.70 \%$, baik $36.70 \%$ dan sangat baik $6.70 \%$, sedangkan pada siklus II kriteria kurang $0.00 \%$, cukup $16.70 \%$, baik $56.70 \%$ dan kriteria sangat baik 26.70 $\%$. Hasil angket tersebut dapat digambarkan pada gambar 2 . 


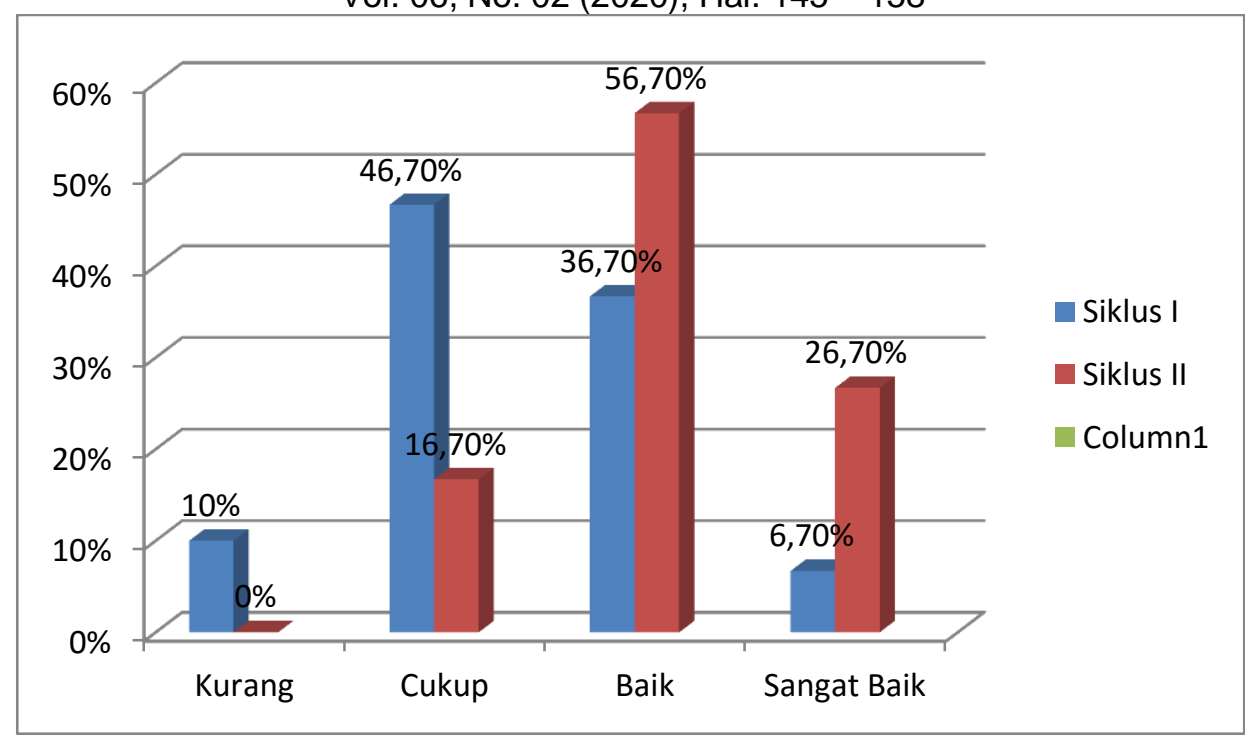

Gambar 2. Grafik Hasil Angket Motivasi Belajar IPA siklus I dan siklus II

Hasil penelitian menghasilkan peningkatan hasil belajar frekuensi 11 (36,67\%) pada skor nilai 61-70. Pada skor 71-80 sebesar 11 (36,67\%). Frekuensi nilai hasil belajar siklus II mendapatkan hasil seperti pada tabel 5 .

Tabel 5. Frekuensi Nilai Hasil Belajar Siklus II

\begin{tabular}{cccc}
\hline Nomor & Nilai & Frekuensi & Prosentase \\
\hline 1 & $21.00-30.00$ & 0 & $0.00 \%$ \\
2 & $31.00-40.00$ & 0 & $0.00 \%$ \\
3 & $41.00-50.00$ & 1 & $3.33 \%$ \\
4 & $51.00-60.00$ & 3 & $10.00 \%$ \\
5 & $61.00-70.00$ & 11 & $36.67 \%$ \\
6 & $71.00-80.00$ & 11 & $36.67 \%$ \\
7 & $81.00-90.00$ & 2 & $6.67 \%$ \\
8 & $91.00-100.00$ & 2 & $6.67 \%$ \\
\hline \multicolumn{5}{c}{ Jumlah } & 30 & $100.00 \%$ \\
\hline
\end{tabular}

Berdasarkan tabel 5 dapat ditegaskan bahwa frekuensi nilai $41.00-50.00$ satu orang $(3.33 \%), 51.00-60.00$ tiga orang $(10.00 \%), 61.00-70.00$ sebelas orang (36.67\%), $71.00-80.00$ sebelas orang(36.67\%), $81.00-90.00$ dua orang $(6.67 \%)$ dan nilai 91.00-100.00.Frekuensi nilai hasil belajar siklus II pada tabel 6 dapat digambarkan dalam gambar 3 . 


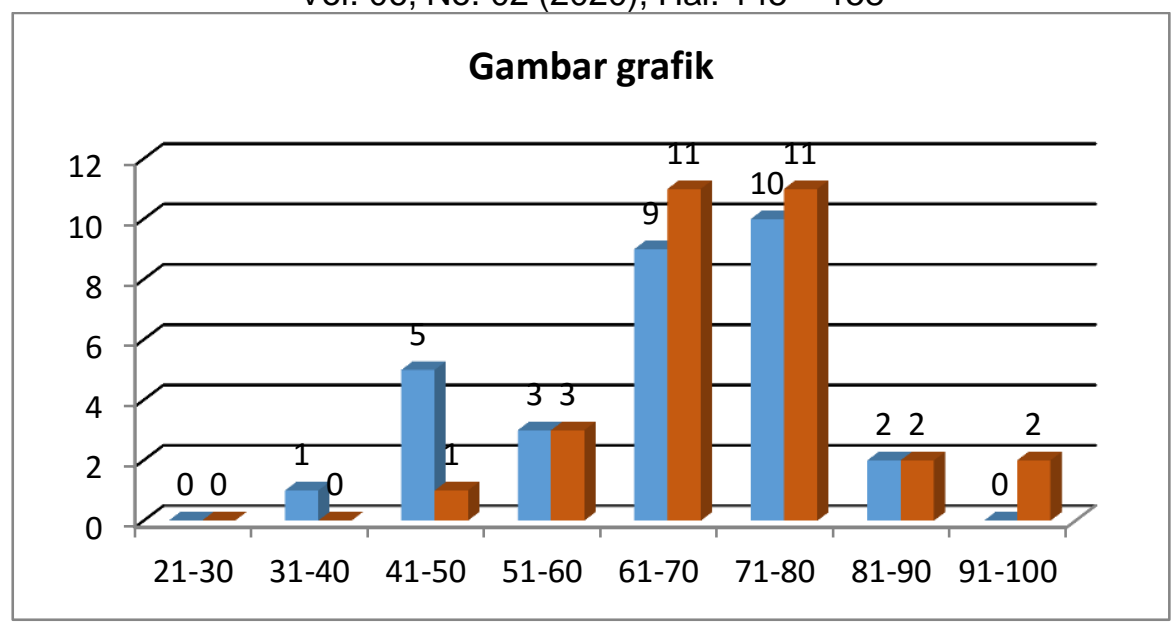

Gambar 3. Grafik frekuensi Nilai Hasil Belajar Siklus I dan Siklus II

Hasil tes kognitif peserta didik pada tes awal, siklus 1 dan siklus II dapat dilihat pada tabel 6 . Hasil tes kognitif rata-rata nilai pada tes awal sebesar 5,5, pada siklus 1 naik menjadi 6,47, dan pada siklus II naik menjadi 7,67.

Tabel 6. Hasil Tes kognitif tiap siklus

\begin{tabular}{cccc}
\hline Keterangan & Tes Awal & Siklus I & Siklus II \\
\hline Nilai terendah & 30.00 & 40.00 & 50.00 \\
Nilai tertinggi & 80.00 & 90.00 & 100.00 \\
Rata-rata nilai & 5.50 & 6.47 & 7.67 \\
Siswa belajar tuntas & $27.00 \%$ & $43.00 \%$ & $86.70 \%$ \\
\hline
\end{tabular}

Berdasarkan tabel 6 dapat ditegaskan bahwa nilai terendah tes awal 30.00, siklus I 40.00 dan siklus II 50.00. Nilai tertinggi tes awal 80.00, siklus I 90.00 dan siklus II 100.00. Rata-rata nilai tes awal 5.50, siklus I 6.47 dan siklus II 7.67. Ketuntasan belajar tes awal $27.00 \%$, siklus I $43.00 \%$ dan siklus II $86.70 \%$.

\section{Deskripsi Hasil Penelitian}

Setelah melaksanakan tindakan pada setiap siklus terjadi peningkatan motivasi belajar peserta didik yang berdampak pada hasil belajar IPA pada konsep sistem peredaran darah dengan menggunakan media pembelajaran modul elektronik. Pada siklus I disampaikan kompetensi dasar mendiskripsikan sistem pernafasan pada manusia dan hubungannya dengan kesehatan dengan indikator: a) menyebutkan macam organ penyusun sistem pernafasan pada manusia, b) membandingkan proses insspirasi dan ekspirasi pada proses pernafasan dan, c) mendata contoh kelainanan dan penyakit pada sistem pernafasan yang biasa dijumpai dalam kehidupan sehari-hari dan upaya mengatasinya, Pembelajaran dengan media balon sedikit mengalami kesulitan karena ada beberapa peserta didik yang bermain-main dengan balonnya. Selama melaksanakan percobaan hanya beberapa siswa tertentu yang aktif, selain itu keberanian siswa maju ke depan untuk mendemonstrasikan dan mempresentasikan hasil percobaan masih kurang. Kegiatan berikutnya guru lebih memperhatikan dan membimbing peserta didik 
sehingga mereka dapat bekerja sama dengan baik serta memberi motivasi agar lebih berani mempresentasikan hasil percobaan di depan kelas.

Pelaksanaan tugas individual maupun tugas kelompok diselesaikan dengan baik karena peserta didik mengalami dan menemukan sendiri konsep kapasitas vital dan kapasitas total paru-paru. Peserta didik berhipotesis, melakukan percobaan, berinteraksi,sehingga pembelajaran menjadi aktif, efektif, kreatif dan menyenangkan.

Pada siklus II

1. Perkembangan hasil belajar afektif siswa sebagai berikut :

a. peserta didik mengerjakan tugas IPA dengan sungguh-sungguh.

b. Kemauan untuk menerima pelajaran dari guru meningkat.

c. Perhatian, minat, dan motivasi terhadap penjelasan guru meningkat.

d. Peserta didik aktif dalam pembelajaran.

e. Peserta didik aktif mengajukan pertanyaan dan pendapat.

f. Kerjasama dalam kelompok meningkat.

g. Tugas individu atau tugas kelompok terlaksana dengan baik.

h. Peserta didik sudah berani mempresentasikan hasil observasi ke depan kelas

2. Perkembangan hasil belajar psikomorik peserta didik sebagai berikut :

a. Menyiapkan kebutuhan belajar tanpa disuruh.

b. Mau mencatat dan merangkum bahan pelajaran dengan baik dan sistematis.

d. Peserta didik sudah berani bertanya dan kepada guru mengenai bahan pelajaran yang masih belum jelas.

e. Banyak peserta didik yang mengangkat tangan mengajukan pertanyaan.

f. Segera membentuk kelompok diskusi.

3. Perkembangan hasil belajar kognitif peserta didik

Berdasarkan hasil pelaksanaan pada siklus I dan II dapat dinyatakan bahwa pembelajaran IPA menggunakan media modul elektronik meningkatkan motivasi belajar peserta didik kelas VIII E SMP Negeri 22 Kota Jambi, dan berdampak positif pada hasil belajar, baik hasil belajar kognitif, afektif maupun psikomotorik.

Pada siklus I setelah diadakan tes kemampuan awal dilanjutkan dengan peserta didik menerima materi sistem pernafasan. Proses pembelajaran disampaikan dengan menggunakan media pembelajaraan berupa balon, terencana dimulai dari kegiatan awal, inti dan penutup. Kegiatan ini terfokus memotivasi belajar dan mengaktifkan peserta didik mulai dari memperhatikan penjelasan, melakukan pengamatan dan percobaan untukmemperoleh kesimpulan, mendemonstrasikan, tugas kelompok, berdiskusi, tugas individual yang diakhiri dengan evaluasi.

Setelah dilaksanakan siklus I dan dievaluasi dapat dilihat adanya peningkatan motivasi belajar peserta didik dan berdampak positif terhadap hasil belajar peserta didik yaitu masih ada 17 orang memperoleh nilai kurang dari 70.00 atau peserta didik yang tuntas $43.00 \%$ dan nilai rata-rata siswa 6.47. Siklus II merupakan lanjutan dari siklus sebelumnya untuk memperbaiki temuan-temuan pada siklus I. Pembelajaran yang disampaikan tentang sistem peredaran darah, kegiatan belajar 
mengajar disampaikan dengan menggunakan media modul elekronik terencana sebagaimana siklus I dan kegiatan pembelajaran dilaksanakan lebih optimal. Hasil siklus II menunjukkan peningkatan motivasi belajar peserta didik, hal ini dapat dilihat dari hasil angket sebagai berikut :kriteria kurang $0.00 \%$, cukup $16.70 \%$, baik 56.70 $\%$ dan kriteria sangat baik $26.70 \%$. Penentuan kriteria ini menggunakan skala Likert, kriteria keberhasilan pada setiap tindakan digunakan rentangan skala 4 (empat) yaitu 4 = sangat baik, skala 3 = baik, skala 2 = cukup, skala 1 = kurang, skala 1 . Meningkatnya motivasi belajar peserta didik ini, berdampak positif pada hasil belajar peserta didik yaitu nilai rata-rata peserta didik 7.67 , ketuntasan belajar mencapai $86.70 \%$ dan hanya 4 peserta didik yang memperoleh nilai di bawah batas nilai ketuntasan.

Hasil penelitian ini sejalan dengan hasil penelitian yang dilakukan oleh Makiyah tentang Upaya Meningkatkan Motivasi Belajar Siswa Melalui Penggunaan Media Audio Visual pada Mata Pelajaran IPS di Kelas V SDN Cempaka Putih 01, dengan hasil penelitian $100 \%$ tercapai untuk hasil observasi guru dan siswa dan $86 \%$ untuk motivasi belajar siswa. Sesuai dengan penyataan Nasution (1996:27) yang menyatakan bahwa penelitian pada suatu saat harus dihentikan bila hasilnya telah memadai atau memuaskan, atau bila peneliti telah sampai pada taraf ketuntasan, maka peneliti memutuskan kegiatan penelitian dihentikan.

\section{KESIMPULAN}

Setelah melakukan Penelitian Tindakan Kelas (PTK) mengenai Meningkatkan motivasi belajar peserta didik menggunakan modul elektronik di kelas VIII E SMP Negeri 22 kota Jambi, dua siklus untuk materi tentang sistem pernafasan dan sistem peredaran darah dapat ditarik kesimpulan bahwa Penggunaan media modul elektronik dapat meningkatkan motivasi belajar peserta didik. Hal ini dibuktikan dengan hasil angket kriteria kurang $0.00 \%$, cukup $16.70 \%$, baik $56.70 \%$ dan kriteria sangat baik $26.70 \%$. nilai rata-rata peserta didik 7.67 , ketuntasan belajar mencapai $86.70 \%$. Disarankan guru harus kreatif memilih media yang menarik untuk memotivasi peserta didik dalam belajar.

\section{UCAPAN TERIMA KASIH}

Terima hasih tak terhingga saya ucapkan kepada :

1. Erdalena, M.Pd sebagai Kepala Sekolah SMP Negei 22 kota Jambi yang telah memberi izin dan memfasilitasi pelaksanaan Penelitian Tindakan Kelas ini.

2. Ade Sosilowati, S.Pd yang telah bersedia menjadi observer di dalam penelitian ini.

3. Ali Sadikin, M.Pd dari Jurnal Biodik yang telah merespon dengan sangat baik pengiriman artikel ini. Semoga Allah SWT membalas semua kebaikan Ibu dan Bapak, Aamiin. 
Daryanto, (2013).Menyusun Modul Bahan Ajar untuk Persiapan Guru dalam Mengajar.Yogyakarta : Gava Media.

Darmawan, Jon. (2018). Menjadi Guru Era Pendidikan 4.0. https://aceh.tribunnews.com/2018/11/27/menjadi-guru-era-pendidikan-40.

Diah, Anngraini, P. (2019). Diakses 18 Maret 2020. Penerapan Media Pembelajaran Fisika Modul Cetak dan Modul Elektronik pada Siswa SMA. Jurnal Pendidikan Fisika, 7 (1), 17-25.

http://journal.uin-alauddin.ac.id/indeks.php/PendidikanFisika.

Anggereini, E. (2017). Pengembangan E-Modul Pembelajaran Lingkungan Hidup Terintegrasi Nilai-Nilai Perilaku Pro Environmental dengan Aplikasi 3D Pageflip Profesional untuk Siswa SMA Sebagai Upaya Menjaga Lingkungan Hidup Berkelanjutan (Sustainable Environment). BIODIK, 3(2), 81-91.

Gunawan, Dedi. (2010). "Modul Pembelajaran Interaktif Elektronika Dasar Untuk Program Keahlian Teknik Audio Video Smk Muhammadiyah 1 Sukoharjo Menggunakan Macromedia Flash 8". Jurnal KomuniTi. 2(1), 60-66.

Kompri.(2016). Motivasi Pembelajaran Perspektif Guru dan Siswa. Bandung: PT Rosda Karya.

Munadi, Sudji, Sunarto, S. dan Wagiran. (2016). diakses 27 Juni 2018. Pengembangan Modul Pembelajaran Kontruktivis Kontekstual Berbantuan Komputer dalam Matadiklat Pemesinan. http://staff.uny.ac.id/sites/default/files/pdf.

Nasution, (1992). Metode Penelitian Naturalistik Kualitatif. Bandung : Tarsito

Rohmad.(2011). Diakses 16 Mei 2020. Usaha Meningkatkan Motivasi dan prestasi belajar siswa dengan menggunakan metode eksperimen yang dibantu media animasi komputer pada materi cahaya di SMP Negeri 1 Tulungagung.

ibrary.um.ac.id/ptk/index.php?mod=subyek\&subyek=KOMPUTER

Rasyidah, Ana, Marzal, J. dan Damris, M. (2015). Diakses 14 Mei 2020. Investigasi Pengetahuan, Keterampilan Dan Implementasi Teknologi Informasi dan Komunikasi (TIK) Guru Matematika SMA/MA Di Kabupaten Tanjung Jabung Barat.Edu-Sains. 4(2), 37-44.

https://media.neliti.com/media/publications/59356-ID-investigasi-pengetahuanketerampilan-dan.pdf

Sugianto, Dony, Abdullah, A.G., Elvyanti, S. dan Muladi, Y.(2013). Diakses tanggal 28 November 2018. Modul Virtual Multimedia Flipbook Dasar Teknik Digital. Invotec 9. (2), 101-116.

https://ejournal.upi.edu/index.php/invotec/article/view/4860/3399

TIM UNY(2016). Diakses tanggal 15 Mei 2020. Modul Vs E-Module http://staffnew.uny.ac.id/upload/198401312014042002/pengabdian/Modul\%20V s\%20E-Module.pdf 